\title{
Co-mutated pathways analysis highlights the coordination mechanism in glioblastoma multiforme
}

\author{
B. WEI ${ }^{1, *}$, L. WANG ${ }^{2, *}$, X. L. ZHAO ${ }^{1}$, Y. JIN ${ }^{3}$, D. L. KONG ${ }^{1}$, G. Z. HU' ${ }^{1}$, Z. G. SUN ${ }^{1,4, *}$ \\ ${ }^{1}$ China-Japan Union hospital of Jilin University, Neurosurgery, Changchun, 130033, China; ${ }^{2}$ The first hospital of Jilin University, Ophthalmology, Changchun, \\ 130021, China; ${ }^{3}$ ilin OilField General Hospital, Songyuan, 131200; ${ }^{4}$ Affiliated Hospital of inner Mongolia University For The Nationalities, China
}

${ }^{*}$ Correspondence: zhigangsun2@hotmail.com

${ }^{*}$ Contributed equally to this work.

Received October 31, 2013 / Accepted January 13, 2014

\begin{abstract}
The mutation of cancer represents a high heterogeneity characteristic, setting a big obstacle in the mechanism study of it. In this study, we explored the distributions of mutated genes in pathways in glioblastoma multiforme (GBM), and constructed networks of co-mutated pathway pairs under the false discovery rate (FDR) control. By comparing the mutation frequencies, a total of 50 mutated genes were screened with the frequency $>3$, and TP53, PTEN, and EGFR were the top 3 genes. By KEGG enrichment, 18 pathways of the mutation gene spectrum of GBM were enriched. These pathways were further studied to explore the coordination between pathways, co-mutated pathway pairs, such as mismatch repair/vascular smooth muscle contraction, mismatch repair/long-term depression, mismatch repair/dopaminergic synapse, and TGF-beta signaling pathway/retrograde endocannabinoid signaling pathway were enriched in the network under FDR $<0.01$; and cell cycle/p53 signaling was a comutated pathway pairs in the network under FDR $<0.05$. Meanwhile, the samples overlap levels of enriched pathways were calculated for further confirming of the co-mutated pathway model. By the co-mutated pathway analysis, the coordination mechanism of cancer can be explored, and it may provide basis for the pathogenesis and combined therapy study of cancer.
\end{abstract}

Key words: co-mutated pathway pairs, gene mutation, glioblastoma multiforme, combined therapy

Cancer is a disease induced by somatic mutations or other molecular alterations in many genes with extreme heterogeneity [1]. The extremely diverse and complex mutational spectrum of cancer has been further revealed by recent highthroughput tumor sequencing studies [2-4]. To elucidate the molecular mechanism of cancer, one important task is to identify the driver mutations, however, it is difficult because genes with low somatic mutation are likely to constitute the vast majority of genes whose mutations contribute to carcinogenesis $[5,6]$. Nowadays, cancer candidate genes are mainly identified according to the mutation frequency of individual genes $[7,8]$. Nevertheless, individual mutation analysis can provide only limited insights into the carcinogenesis, which may not be able to match that cancer is a progressive disease involving multiple mutations acting in concert [9]. Pathway analysis provides more information about cancer and may help us to understand the mechanisms.

It is widely accepted that pathways often function cooperatively in carcinogenesis [10-12]. For example, based on large-scale somatic mutation profile of lung adenocarcinoma, Gu et al [13] identify mangy pairs of significantly co-mutated pathways. Mann et al [14] conduct a mutagenic screen using sleeping beauty, and the cooperating mutations and pathways in pancreatic adenocarcinoma are revealed. The mutations of genes in different patients could cause equivalent pathway changes to induce cancer [15]. Thus, the identification of cooperation of genes mutation and pathways is of great importance during carcinogenesis [16].

Glioblastoma multiforme (GBM) is the most common and lethal type of brain cancer in humans [3]. Researches show that genes tend to be co-mutated in cancer, and the co-mutated genes are more likely to distribute in different pathways $[17,12]$. In the present study, the pathways with co-mutated genes were defined as co-mutated pathway pairs. Then, the pathway distributions of mutated genes of GBM were assessed, and networks of co-mutated pathway pairs were constructed under the control of false discovery rate (FDR) to explore the cooperation of pathways [2]. 

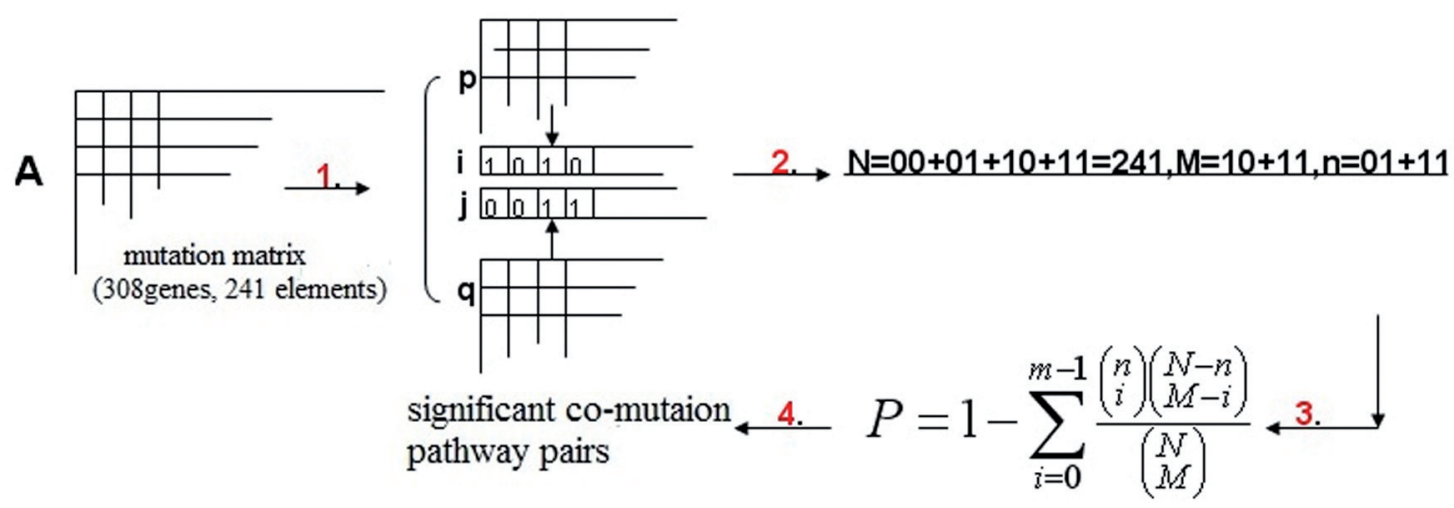

Figure 1. Method used in co-mutated pathway pairs screening

\section{Material and methods}

GBM mutation data. The GBM mutation data were downloaded from The Cancer Genome Atlas (TCGA, https:// tcga-data.nci.nih.gov/tcga/tcgaHome2.jsp/) database, including 7 batches (Batch1, 2, 3, 4, 6, 7 and 8), 3 testing platforms (BCM_ABI, BI_ABI and WUSM_ABI) and 3 levels. Data from 7 batches and 3 platforms were integrated, and genes with same sense mutation and those not corresponding to Entrez _ Gene _Id were removed, to obtain the mutation spectrum of GBM. The mutation spectrum is comprised of 241 mutation samples and 308 mutation genes, with 701 non-same sense mutations. The frequencies of the mutation genes were calculated to screen the genes highly related with GBM.

Pathway enrichment. DAVID (The Database for Annotation, Visualization and Integrated Discovery) provides a comprehensive set of functional annotation tools helping investigators to understand biological meaning behind the large list of genes, of which Fisher is a annotation tool [18]. The Kyoto Encyclopedia of Genes and Genomes (KEGG) pathway database [19] contains information of how molecules or genes network, displays intracellular biological process by diagrams. Considering that signaling pathways abnormality plays an important role in the proliferation and metastasis, four pathways: genetic information processing, environmental information processing, cellular processes and organismal system of KEGG were chosen for mutation genes pathway enrichment, containing 122 pathways. Fisher was used to identify significant pathways in the four processes with hypergeometric distribution under the false discovery false $($ FDR $)<0.1$.

Scoring Co-mutated pathway pairs. The cooperation between pathways were identified according to the method reported by Gu et al [13]. Firstly, the mutation matrix was constructed from the mutation spectrum: 241 samples with 308 mutated genes, the element of samples with mutated genes will be given the value 1 , otherwise, the element will be 0 ; secondly, the $[0,1]$ vector of interactive pathway pairs was constructed, containing 241 elements. The value 1 represents that mutated genes existed in this pathway, 0 represents no mutated genes existed; finally, co-mutated pathway pairs were screened by hypergeometric distribution and [0 1] vector according to the FDR value. The method model was diagramed in figure 1.

Co-mutated pathway pairs network construction. In order to explore the interaction between pathways in the occurrence of cancer, the interaction networks of co-mutated pathway pairs were constructed according to FDR values. Meanwhile, the sample overlap levels of the pathways in network were calculated.

\section{Results}

Gene mutation frequency. GBM closely related mutation genes were screened by comparing mutation frequency of 308 mutation genes. Genes with frequency not less than 3 are shown in table 1. Tumor suppressor gene TP53, PTEN and proto-oncogene EGFR were the top 3 genes with the highest frequencies. The different frequencies further confirmed the heterogeneity of GBM carcinogenesis. What's more, among all the mutation genes, there were many novel GBM related genes, such as FKBP9, BCL11A, ITPR3, ANK2, ROR2, DDR2, and PSMD13.

Pathway annotation. By DAVID, a total of 18 significant pathways of 308 mutation genes were enriched under FDR $<0.1$, as shown in table 2 . The nodes of these pathways were divided mainly into several categories: disease, pathways in cancer and Glioma; signaling transduction, ErbB signaling pathway and Phosphatidylinositol signaling system; cell growth and death, p53 signaling pathway; signaling transduction, Focal adhesion and Adherent junction; cell movement, Regulation of actin cytoskeleton; excretory system, Aldosterone-regulated sodium reabsorption. The Glioma pathway and mutation genes enriched in this pathway are shown in figure 2 .

Pathways with the higher sample overlap levels may have closer relationship with diseases. The top 30 pathways of the GBM mutation genes listed according to sample overlap levels are shown in table 3. Pathways related with the carcinogenesis of cancer, such as Focal adhesion, MAPK signaling pathway, 
Table 1. GBM closely related genes by mutation frequency

\begin{tabular}{|c|c|c|c|c|c|c|c|c|c|}
\hline Gene & Fr & Gene & $\mathrm{Fr}$ & Gene & Fr & Gene & Fr & Gene & Fr \\
\hline $\begin{array}{l}\text { TP53 (tumor protein } \\
\text { p53) }\end{array}$ & 68 & $\begin{array}{l}\text { SYNE1 (spectrin repeat } \\
\text { containing, nuclear } 1 \text { ) }\end{array}$ & 7 & $\begin{array}{l}\text { ITGB3 (integrin, beta } \\
\text { 3) }\end{array}$ & 4 & $\begin{array}{l}\text { EPHA7 (ephrin receptor } \\
\text { A7) }\end{array}$ & 3 & $\begin{array}{l}\text { PSMD13 (26S proteasome } \\
\text { non-ATPase regulatory) }\end{array}$ & 3 \\
\hline $\begin{array}{l}\text { PTEN (phosphatase } \\
\text { and tensin homolog) }\end{array}$ & 52 & $\begin{array}{l}\text { PRKCD (protein kinase } \\
\text { C, delta) }\end{array}$ & 6 & $\begin{array}{l}\text { ITPR3 (inositol 1,4,5- } \\
\text { triphosphate receptor } 3 \text { ) }\end{array}$ & 4 & FN1 (fibronectin 1) & 3 & $\begin{array}{l}\text { TNFRSF10A (tumor } \\
\text { necrosis factor receptor } \\
\text { superfamily 10A) }\end{array}$ & 3 \\
\hline $\begin{array}{l}\text { EGFR (epidermal } \\
\text { growth factor } \\
\text { receptor) }\end{array}$ & 36 & $\begin{array}{l}\text { ST6GAL1 (ST6 beta- } \\
\text { galactosamide alpha 2, } \\
\text { 6-sialyltransferase) }\end{array}$ & 6 & $\begin{array}{l}\text { MET (met proto- } \\
\text { oncogene) }\end{array}$ & 4 & $\begin{array}{l}\text { GSTM5 (glutathione } \\
\text { S-transferase mu 5) }\end{array}$ & 3 & $\begin{array}{l}\text { MLL4 (myeloid/lymphoid } \\
\text { or mixed-lineage leukemia } \\
\text { 4) }\end{array}$ & 3 \\
\hline RB1 (retinoblastoma 1) & 16 & $\begin{array}{l}\text { FKBP9 (FK506 binding } \\
\text { protein 9) }\end{array}$ & 6 & $\begin{array}{l}\text { PDGFRA (platelet } \\
\text { derived growth factor } \\
\text { receptor alpha) }\end{array}$ & 4 & $\begin{array}{l}\text { HLA-E (major } \\
\text { histocompatibility } \\
\text { complex, class I, E) }\end{array}$ & 3 & $\begin{array}{l}\text { TNK2 (tyrosine kinase, } \\
\text { non-receptor, 2) }\end{array}$ & 3 \\
\hline $\begin{array}{l}\text { IDH1 (isocitrate } \\
\text { dehydrogenase 1) }\end{array}$ & 10 & $\begin{array}{l}\text { FGFR1 (fibroblast } \\
\text { growth factor receptor 1) }\end{array}$ & 5 & $\begin{array}{l}\text { TEK (tyrosine kinase, } \\
\text { endothelial) }\end{array}$ & 4 & TNC (tenascin C) & 3 & $\begin{array}{l}\text { MYST4 (MYST histone } \\
\text { acetyltransferase } \\
\text { monocytic) }\end{array}$ & 3 \\
\hline $\begin{array}{l}\text { PIK3C2G } \\
\text { (phosphoinositide- } \\
\text { 3-kinase, class 2, } \\
\text { gamma) }\end{array}$ & 10 & $\begin{array}{l}\text { CHEK2 (checkpoint } \\
\text { kinase 2) }\end{array}$ & 5 & $\begin{array}{l}\text { RHPN2 (rhophilin, } \\
\text { Rho GTPase binding } \\
\text { protein 2) }\end{array}$ & 4 & $\begin{array}{l}\text { KIT ( tyrosine kinase } \\
\text { receptor ) }\end{array}$ & 3 & $\begin{array}{l}\text { PRAME (preferentially } \\
\text { expressed antigen in } \\
\text { melanoma) }\end{array}$ & 3 \\
\hline $\begin{array}{l}\text { PIK3R1 } \\
\text { (phosphatidylinositol } \\
\text { 3-kinase, regulatory } \\
\text { subunit 1) }\end{array}$ & 8 & $\begin{array}{l}\text { BCL11A (B-cell CLL/ } \\
\text { lymphoma 11A (zinc } \\
\text { finger protein)) }\end{array}$ & 5 & ANK2 (Ankyrin 2) & 3 & $\begin{array}{l}\text { LGALS3BP (lectin, } \\
\text { galactoside-binding, } \\
\text { soluble, } 3 \text { ) }\end{array}$ & 3 & $\begin{array}{l}\text { FBXW7 (F-box and WD } \\
\text { repeat domain containing } \\
7 \text { ) }\end{array}$ & 3 \\
\hline LUM (lumican) & & $\begin{array}{l}\text { COL1A1 (collagen, type } \\
\text { I, alpha } 1 \text { ) }\end{array}$ & & $\begin{array}{l}\text { BRCA2 (breast cancer } \\
\text { 2) }\end{array}$ & & $\begin{array}{l}\text { ROR2 (receptor tyrosine } \\
\text { kinase-like orphan 2) }\end{array}$ & & $\begin{array}{l}\text { ADAMTSL3 (A } \\
\text { disintegrin-like and }\end{array}$ & \\
\hline & 7 & & 4 & & 3 & & 3 & $\begin{array}{l}\text { metalloprotease domain } \\
\text { with thrombospondin type } \\
\text { I motifs-like } 3 \text { ) }\end{array}$ & 3 \\
\hline NF1 (neurofibromin 1) & 7 & $\begin{array}{l}\text { CYP27B1 ( cytochrome } \\
\text { P450, family } 27 \\
\text { subfamily B 1) }\end{array}$ & 4 & $\begin{array}{l}\text { CDKN2A (cyclin- } \\
\text { dependent kinase } \\
\text { inhibitor } 2 \mathrm{~A} \text { ) }\end{array}$ & 3 & $\begin{array}{l}\text { DDR2 (discoidin } \\
\text { domain receptor } \\
\text { tyrosine kinase } 2 \text { ) }\end{array}$ & 3 & PAPPA2 (pappalysin 2) & 3 \\
\hline $\begin{array}{l}\text { PIK3CA } \\
\text { (phosphoinositide-3- } \\
\text { kinase, catalytic A) }\end{array}$ & 7 & $\begin{array}{l}\text { MSH6 ( DNA mismatch } \\
\text { repair protein) }\end{array}$ & 4 & $\begin{array}{l}\text { DOCK1 (dedicator of } \\
\text { cytokinesis } 1 \text { ) }\end{array}$ & 3 & $\begin{array}{l}\text { PIK3CG } \\
\text { (phosphoinositide-3- } \\
\text { kinase, catalytic) }\end{array}$ & 3 & $\begin{array}{l}\text { ABCA13 (ATP-binding } \\
\text { cassette, sub-family } \\
\text { A }(\mathrm{ABC} 1) \text { ) }\end{array}$ & 3 \\
\hline
\end{tabular}

Fr: frequency

Table 2. Significant pathways of mutation genes

\begin{tabular}{lccc}
\hline Term & Gene count & P Value & FDR \\
\hline Pathways in cancer & 39 & $1.87 \mathrm{E}-12$ & $2.28 \mathrm{E}-10$ \\
Focal adhesion & 30 & $5.26 \mathrm{E}-12$ & $6.41 \mathrm{E}-10$ \\
Melanoma & 15 & $4.31 \mathrm{E}-08$ & $5.26 \mathrm{E}-06$ \\
Endometrial cance & 12 & $6.10 \mathrm{E}-07$ & $7.44 \mathrm{E}-05$ \\
Glioma & 13 & $6.19 \mathrm{E}-07$ & $7.55 \mathrm{E}-05$ \\
Prostate cancer & 15 & $8.19 \mathrm{E}-07$ & $9.99 \mathrm{E}-05$ \\
Non-small cell lung cancer & 12 & $9.13 \mathrm{E}-07$ & $1.11 \mathrm{E}-04$ \\
Pancreatic cancer & 13 & $2.76 \mathrm{E}-06$ & $3.36 \mathrm{E}-04$ \\
Colorectal cancer & 13 & $1.44 \mathrm{E}-05$ & 0.001759 \\
Phosphatidylinositol signaling system & 12 & $2.26 \mathrm{E}-05$ & 0.002757 \\
Regulation of actin cytoskeleton & 20 & $6.09 \mathrm{E}-05$ & 0.007398 \\
Aldosterone-regulated sodium & & & \\
reabsorption & 8 & $3.07 \mathrm{E}-04$ & 0.036717 \\
p53 signaling pathway & 10 & $3.19 \mathrm{E}-04$ & 0.038183 \\
Bladder cancer & 8 & $3.58 \mathrm{E}-04$ & 0.042735 \\
ErbB signaling pathway & 11 & $4.78 \mathrm{E}-04$ & 0.056689 \\
Chronic myeloid leukemia & 10 & $6.69 \mathrm{E}-04$ & 0.078364 \\
Type II diabetes mellitus & 8 & $7.27 \mathrm{E}-04$ & 0.084948 \\
Adherens junction & 10 & $8.12 \mathrm{E}-04$ & 0.094378 \\
\hline FDR: false discovery rate & & &
\end{tabular}

FDR: false discovery rate p53 signaling pathway, Cell cycle, Apoptosis, Wnt signaling pathway, mTOR signaling pathway ranked top in the list, suggesting that these pathways were closely related with the occurrence of GBM.

Co-mutated pathway pairs. Co-mutated pathway pairs cooperated in the GBM process, and they were enriched by hypergeometric distribution. Numbers of the pairs with different FDR values were displayed in table 4 .

Co-mutated pathways network. Under the level of FDR $<0.01,22$ co-mutated pathway pairs were chosen, and a co-mutated pathways network was constructed based on these 22 pairs (figure 3 ) to help to elucidate the interactions between pathways. Mismatch repair, TGF-beta signaling pathway are the two hub pathways with the highest degrees (connection numbers of pathways). There were 10 and 5 pathways connected with mismatch repair pathway and TGFbeta signaling pathway respectively. Pathways related with Nervous system, such as Dopaminergic synapse, signaling Retrograde endocannabinoid, Long-term depression and Glutamatergic synapse were also mapped in this network, 
GLIOMA

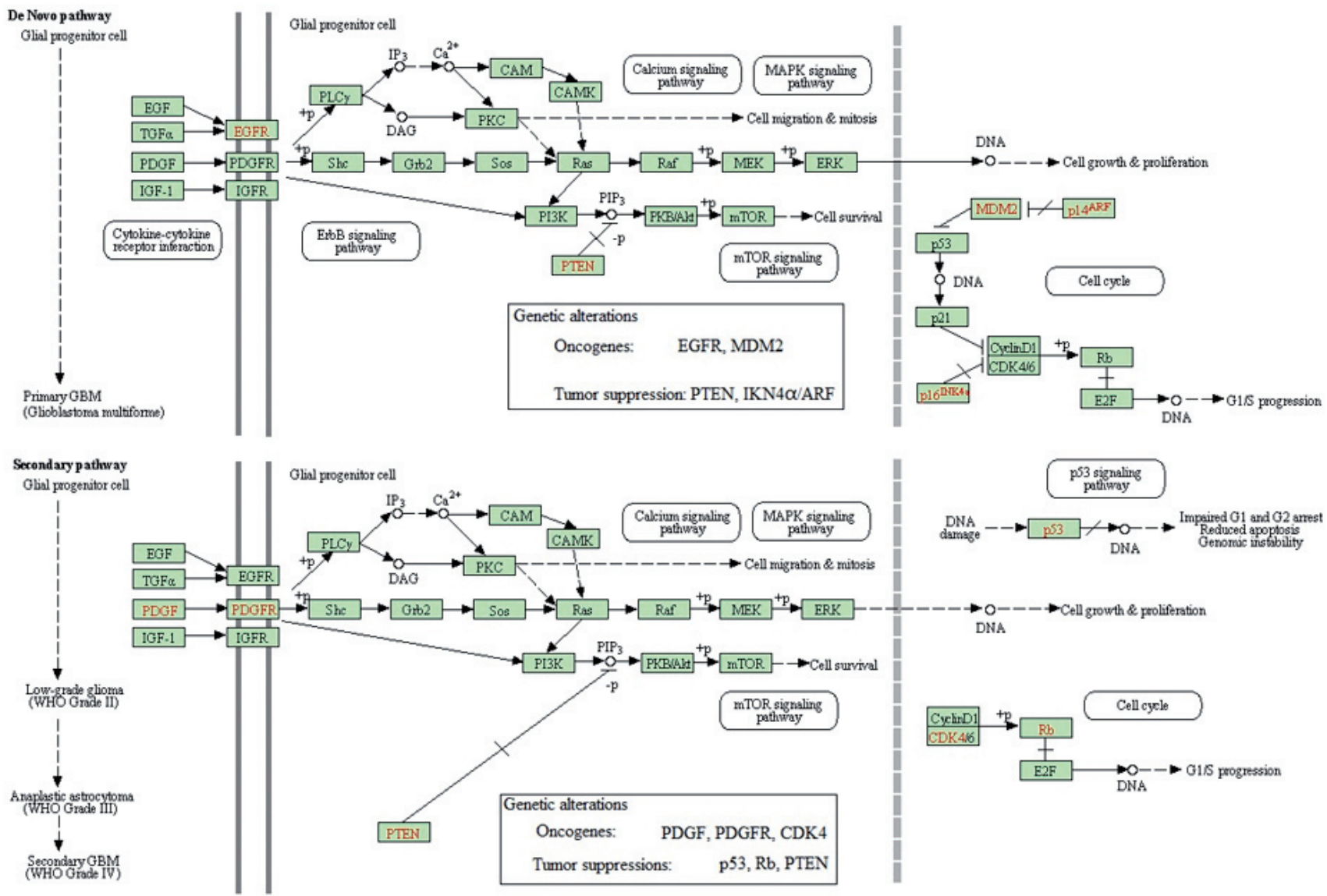

Figure 2. Glioma pathway. The red genes are mutation genes enriched in this way.

suggesting the important roles of nervous system dysfunction in GBM carcinogenesis. It can be also seen from figure 2, that ErbB signaling pathway/Adherens junction $(\mathrm{FDR}=0.0095)$, Cytokine-cytokine receptor interaction/Regulation of actin cytoskeleton $(\mathrm{FDR}=0.0032)$, Jak-STAT signaling pathway/ Natural killer cell mediated cytotoxicity $(\mathrm{FDR}=0.0032)$ were co-mutated pathway pairs, even though their degrees were low. Meanwhile, the sample overlap levels of the pathways in the network were calculated (table 5). Regulation of actin cytoskeleton, ErbB signaling pathway and Cytokine receptor interaction were the top 3 pathways, they have close relationship with GBM.

Under the level of FDR $<0.05,132$ co-mutated pathway pairs were chosen, and a co-mutated pathways network was constructed based on these pairs (figure 4). Cell cycle/p53 signaling pathway $(\mathrm{FDR}=0.04433)$ was an important pair in the network. Furthermore, cytokine-cytokine receptor interaction-MAPK signaling pathway $(\mathrm{FDR}=0.06957)$, and Wnt signaling pathway-Neurotrophin signaling pathway had the trend to co-mutate $(\mathrm{FDR}=0.05858)$.

\section{Discussion}

Cancer is a progressive disease caused by the mutations of various genes in different pathways [13]. To fully elucidate the mechanisms of the carcinogenesis, studies on pathway and genes collaboration are very necessary. In this study, we assessed the mutation frequencies of 308 mutation genes of GBM, and then conducted a pathway enrichment of all the genes. The comutated pathway pairs were screened with the control of FDR, and two interaction networks of co-mutated pathway pairs were constructed under the FDR value 0.05 and 0.01 .

TP53, PTEN, and EGFR are the top three genes with high mutation frequency. TP53 is undoubtedly the most influential genetic factor related to the occurrence of the human brain tumors [20]. The type and distribution of TP53 mutations differs between GBM subtypes [21]. EGFR amplification and mutation are invariably expressed in a heterogeneous manner in GBM [22], and the genomic alterations of EGFR play a crucial role in pathogenesis of GBM [23]. Decreased PTEN expression has been shown in GBM [24-26]. 


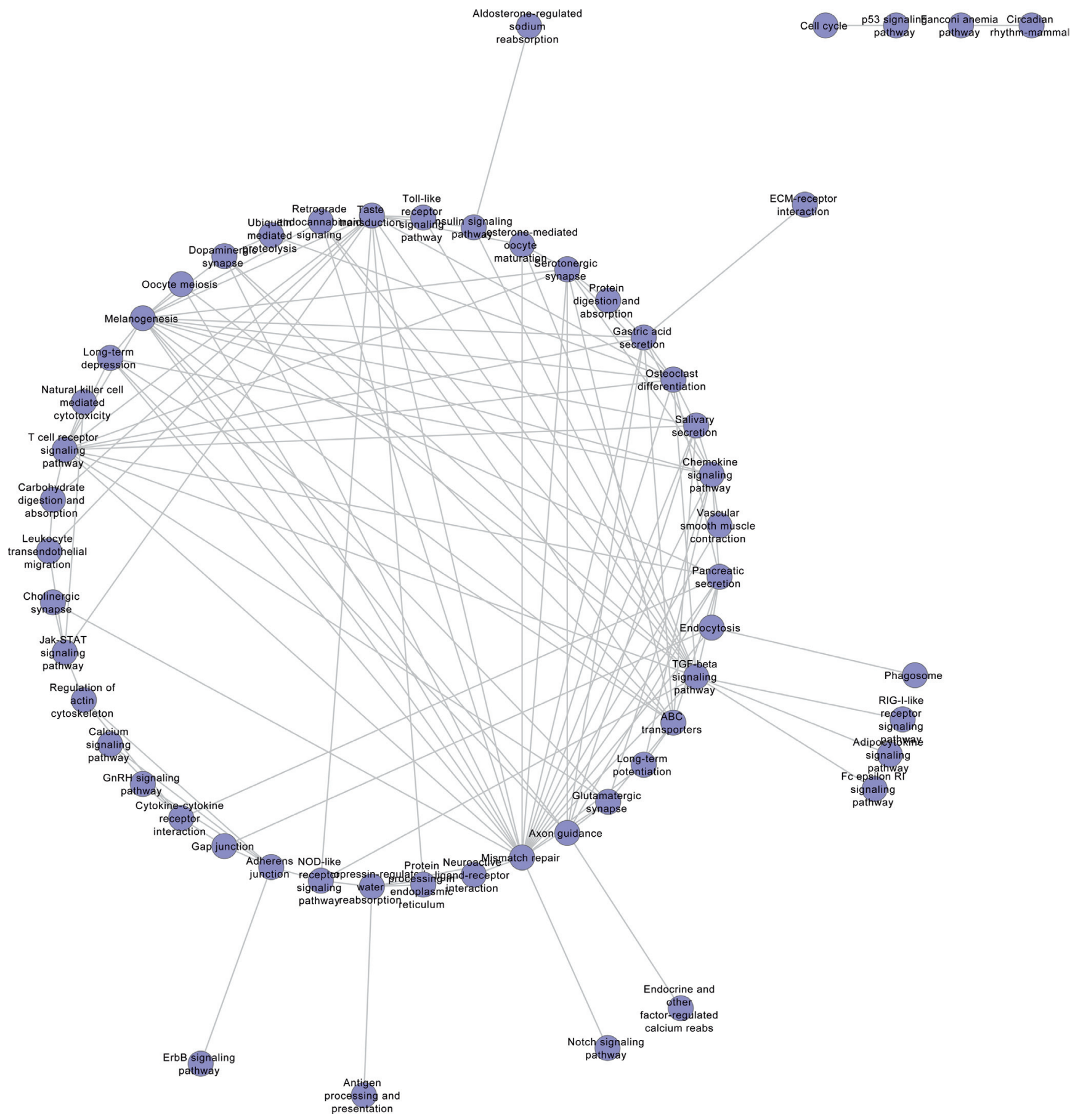

Figure 3. Interaction networks of co-mutated pathways under false discovery rate $<0.01$. The nodes represent pathways, and the edges between pathways represent their co-mutated relationship.

Mismatch repair was a hub pathway in the network under FDR $<0.01$. We deduced that genes mutation in the hub pathway of mismatch repair can increase the mismatch mutation in the samples, which can sequentially increase the co-mutation in GBM, and thus the risk of GBM increases. DNA mismatch repair targets errors generated during DNA replication, and plays an essential role in maintaining genomic fidelity and stability [27]. Mismatch repair may go awry in GBM [28]. Reduced expression of mismatch repair proteins (MSH) is characteristic of GBM recurring after current standards of 


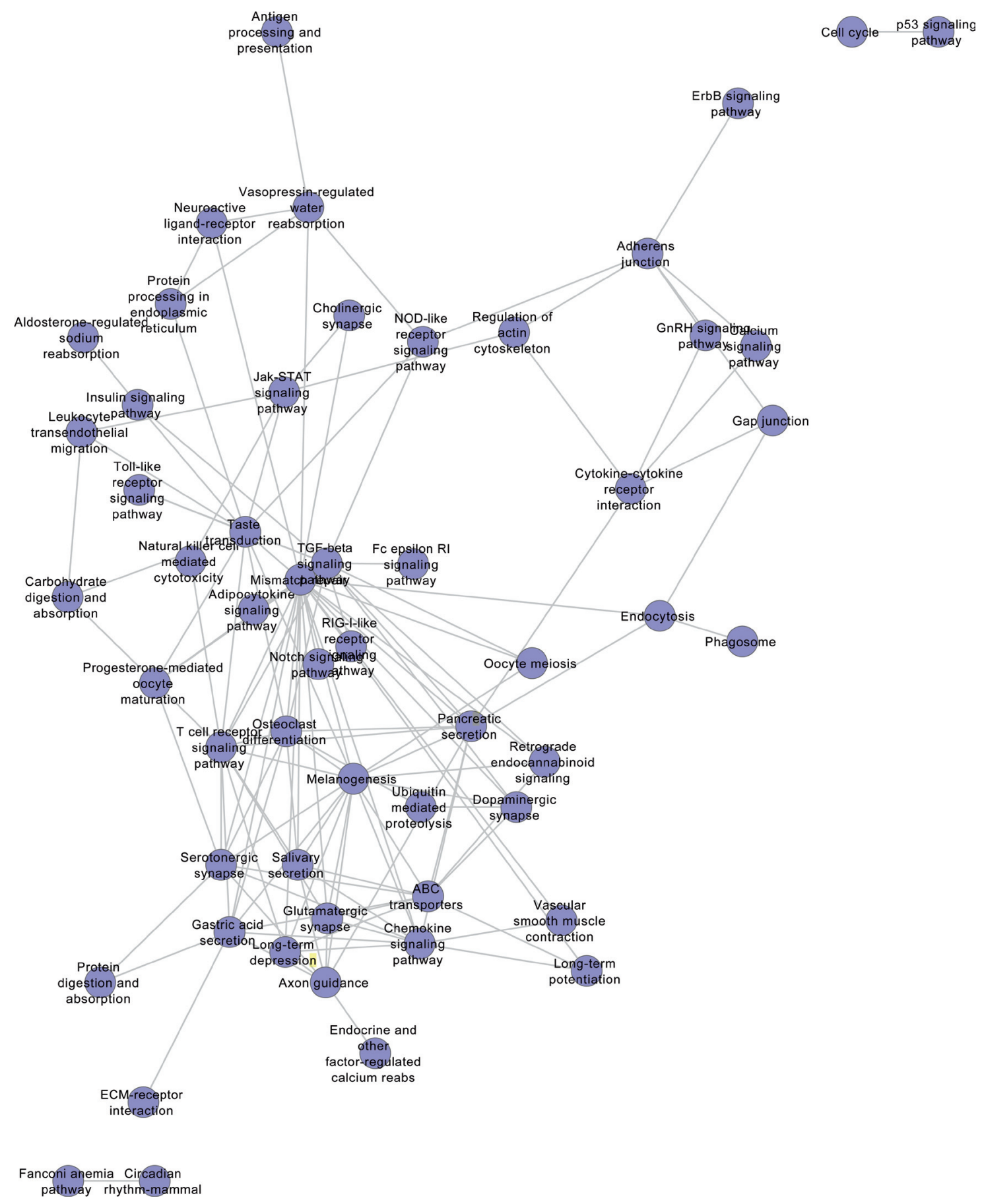

Figure 4. Interaction networks of co-mutated pathways under false discovery rate $<0.05$. The nodes represent pathways, and the edges between pathways represent their co-mutated relationship.

care, and MSH6 mutations are reported in three glioblastoma specimens [29]. Vascular smooth muscle contraction pathway, long-term depression pathway, and Glutamatergic synapse were co-mutated pathways of mismatch repair. Vascular smooth muscle contraction pathway is involved in the regula- tion of the blood flow and pressure. By gene set enrichment and meta-analysis, vascular smooth muscle contraction and long-term depression pathways are enriched to be closely related with the set of imported glioma genes [30]. PRKCB is associated with the vascular smooth muscle contraction and 
Table 3. Top 30 pathways according to samples overlap levels

\begin{tabular}{|c|c|c|c|}
\hline name & $\begin{array}{l}\text { Gene } \\
\text { count }\end{array}$ & $\begin{array}{c}\text { Mutation } \\
\text { number }\end{array}$ & $\begin{array}{c}\text { Sample } \\
\text { size }\end{array}$ \\
\hline Pathways in cancer & 325 & 39 & 155 \\
\hline Prostate cancer & 89 & 15 & 148 \\
\hline Melanoma & 71 & 15 & 146 \\
\hline Glioma & 65 & 13 & 144 \\
\hline Endometrial cancer & 52 & 12 & 139 \\
\hline Small cell lung cancer & 84 & 7 & 119 \\
\hline Pancreatic cancer & 70 & 13 & 118 \\
\hline Non-small cell lung cancer & 54 & 12 & 117 \\
\hline Focal adhesion & 200 & 30 & 116 \\
\hline MAPK signaling pathway & 268 & 20 & 116 \\
\hline p53 signaling pathway & 68 & 10 & 112 \\
\hline Hepatitis C & 131 & 10 & 110 \\
\hline Bladder cancer & 42 & 8 & 106 \\
\hline HTLV-I infection & 263 & 22 & 105 \\
\hline Epstein-Barr virus infection & 203 & 15 & 98 \\
\hline Neurotrophin signaling pathway & 125 & 11 & 93 \\
\hline Chronic myeloid leukemia & 73 & 10 & 92 \\
\hline Cell cycle & 124 & 11 & 85 \\
\hline Colorectal cancer & 62 & 9 & 85 \\
\hline Measles & 136 & 10 & 85 \\
\hline Apoptosis & 87 & 7 & 82 \\
\hline Phosphatidylinositol signaling system & 81 & 12 & 82 \\
\hline Transcriptional misregulation in cancer & 180 & 15 & 82 \\
\hline Herpes simplex infection & 184 & 9 & 77 \\
\hline Wnt signaling pathway & 151 & 11 & 77 \\
\hline Basal cell carcinoma & 55 & 7 & 75 \\
\hline Inositol phosphate metabolism & 61 & 7 & 72 \\
\hline Huntington disease & 184 & 3 & 71 \\
\hline mTOR signaling pathway & 64 & 8 & 70 \\
\hline Regulation of actin cytoskeleton & 212 & 20 & 70 \\
\hline
\end{tabular}

Table 4. Numbers of co-mutated pathway airs under different false discovery rate (FDR)

\begin{tabular}{ccccc}
\hline & $\mathrm{FDR}<=0.01$ & $\mathrm{FDR}<=0.05$ & $\mathrm{FDR}<=0.1$ & $\mathrm{FDR}<=0.2$ \\
\hline Numbers & 22 & 132 & 295 & 680 \\
\hline
\end{tabular}

long term depression pathway in glioma [30], and is a gene with a higher lifetime death hazard in male GBM patients than in females [31]. So, we induce that MSH6 in mismatch repair pathway and PRKCB in vascular smooth muscle contraction and long term depression pathway co-mutated, causing the collaboration of these pathways in the carcinogenesis of GBM. The neurotransmitter glutamate is produced and released from glioma cells as a byproduct of glutathione synthesis, glioblastoma tumors release glutamate to enhance their highly malignant behavior, and in fact, the invasive nature of gliomas enhanced by glutamate release is one of the most important limitations to effective disease control [32].

TGF-beta signaling pathway was another hub pathway in the network under FDR $<0.01$, and retrograde endocannabinoid signaling was one co-mutated pathway of it. TGF-beta signaling pathway acts as an oncogenic factor in GBM and is considered a therapeutic target [33]. TGF-beta signaling pathway is a unique therapeutic target compared to the other commonly studied signaling pathways in GBM in that it may represent an important crosslink to various intracellular processes [34]. TGF-beta can function as a tumor suppression gene in GBM, and can alter collagen synthesis, cell adhesion and invasiveness in gliomas $[35,36]$. Endocannabinoids functions as retrograde signaling molecular at synapses throughout the brain [37], and plays an anti-proliferative effect upon rat C6 glioma cells [38]. Cannabinoids have displayed a great potency in reducing glioma tumor growth either in vitro or in animal experimental model, and a pilot clinical trial on patients with GBM demonstrate that cannabinoids have good safety profile and remarkable antitumor effects[39]. The impaired tumor growth of GBM in presence of cannabinoids may be involved with the activation of cannabinoids 2 (CB2), and the expression and distribution of CB2 receptorsare abundant in GBM [40]. The research of Gardner et al suggests that TGF-beta actively regulates lymphocyte $\mathrm{CB} 2$ receptor expression in an autocrine and paracrine manner [41]. Similarly, TGF-beta signaling pathway and retrograde endocannabinoid signaling pathway may be comutated through the co-mutation of TGF-beta and CB2 in GBM. Cytokine-cytokine receptor interaction pathway was related to the tumorigenesis and signaling transduction in the progress of

Table 5. Sample overlap levels of hub pathways in the network

\begin{tabular}{lcl}
\hline name & number & name \\
\hline Mismatch repair & 5 & Dopaminergic synapse \\
RIG-I-like receptor signaling pathway & 5 & Vascular smooth muscle contraction \\
Taste transduction & 6 & T cell receptor signaling pathway \\
Pancreatic secretion & 7 & Progesterone-mediated oocyte maturation \\
Salivary secretion & 8 & Toll-like receptor signaling pathway \\
Serotonergic synapse & 8 & Jak-STAT signaling pathway \\
Gastric acid secretion & 914 & Natural killer cell mediated cytotoxicity \\
Melanogenesis & 92 & Chemokine signaling pathway \\
TGF-beta signaling pathway & 9 & Adherens junction \\
Glutamatergic synapse & 9 & Cytokine-cytokine receptor interaction \\
Long-term depression & 10 & ErbB signaling pathway \\
Retrograde endocannabinoid signaling & 10 & Regulation of actin cytoskeleton \\
\hline
\end{tabular}


glioma [42]. The actin cytoskeleton is a dynamic structure that plays a fundamental role in diverse process in all eukaryotic cells [43]. The regulation of actin cytoskeleton pathway and cytokinecytokine receptor interaction pathway were enriched in the co-mutated pathway network in this study, suggesting that they may play a cooperating work in the carcinogenesis of GBM.

The p53 signaling pathway exerts an important role in glioma pathogenesis [44], and it is an inactivating mutation of p53 signaling pathway in GBM. The type and distribution of p53 may differ between GBM subtypes [34]. MAPK signaling pathway is involved in GBM cell migration and proliferation [45], and it is one changed pathway in glioma [30]. Thus p53 signaling pathway and MAPK signaling pathway are changed in GBM. However, they were not mapped in the network of co-mutated pathway pairs, suggesting that not all the carcinogenesis close related pathways will co-mutate with other pathways.

Nevertheless, in the network under FDR $<0.05$, cell cycle/p53 signaling pathway was found to co-mutate. The p53 pathway, which mutates inactively in GBM [34], is most intensely implicated in cell cycling regulation during times of cell repair and cell growth, and the mutation of $\mathrm{p} 53$ will cause the impaired G1 and G2 arrest [34].

Judged from the two networks of co-mutated pathway pairs, some enriched pathways co-mutated with other pathways in monotonous model such as Cell cycle-p53 signaling pathway, Cytokine-cytokine receptor interaction-MAPK signaling pathway), that is, the connection degrees of the hub pathways were usually not so high.

By the co-mutated pathway analysis, the coordination mechanism of cancer can be explored, which may provide basis for the pathogenesis and combined therapy study of cancer. The pathways changed in GBM and their co-mutated relationships can be detected by the method used in this study.

Acknowledgments: This study was supported by Science and Technology Development Program Of Jilin Province (20140520034JH), The 4th Youth Fund of the First Hospital of Jilin University (JDYY42013007) and Young Scholars Program of Norman Bethune Health Science Center of Jilin University (2013205030).

\section{References}

[1] VOGELSTEIN B, KINZLER KW. Cancer genes and the pathways they control. Nat Med. 2004; 10: 789-799. http://dx.doi. org/10.1038/nm1087

[2] WANG J, ZHANG Y, SHEN X, ZHU J, ZHANG L et al. Finding co-mutated genes and candidate cancer genes in cancer genomes by stratified false discovery rate control. Mol Biosyst. 2011; 7: 1158-1166. http://dx.doi.org/10.1039/c0mb00211a

[3] PARSONS DW, JONES S, ZHANG X, LIN JC-H, LEARY RJ et al. An integrated genomic analysis of human glioblastoma multiforme. Science. 2008; 321: 1807-1812. http://dx.doi. org/10.1126/science.1164382

[4] Jones S, Zhang X, PARSONS DW, LIN JC-H, LEARY RJ et al. Core signaling pathways in human pancreatic cancers revealed by global genomic analyses. Sci Signal. 2008; 321: 1801.

[5] BEROUKHIM R, GETZ G, NGHIEMPHU L, BARRETINA J, HSUEH T et al. Assessing the significance of chromosomal aberrations in cancer: methodology and application to glioma. Proc Natl Acad Sci. 2007; 104: 20007-20012. http://dx.doi. org/10.1073/pnas.0710052104

[6] BLEEKER FE, LAMBA S, RODOLFO M, SCARPA A, LEENSTRA S et al. Mutational profiling of cancer candidate genes in glioblastoma, melanoma and pancreatic carcinoma reveals a snapshot of their genomic landscapes. Hum Mutat. 2009; 30: E451-E459. http://dx.doi.org/10.1002/humu.20927

[7] SJ BLOM T, JONES S, WOOD LD, PARSONS DW, LIN J et al. The consensus coding sequences of human breast and colorectal cancers. Science. 2006; 314: 268-274. http://dx.doi. org/10.1126/science.1133427

[8] DING L, GETZ G, WHEELER DA, MARDIS ER, MCLELLAN MD et al. Somatic mutations affect key pathways in lung adenocarcinoma. Nature. 2008; 455: 1069-1075. http://dx.doi. org/10.1038/nature07423

[9] NIBBE RK, KOYUT RK M, CHANCE MR. An integrativeomics approach to identify functional sub-networks in human colorectal cancer. PLoS Comput Biol. 2010; 6: e1000639. http://dx.doi.org/10.1371/journal.pcbi.1000639

[10] KLIJN C, BOT J, ADAMS DJ, REINDERS M, WESSELS L et al. Identification of networks of co-occurring, tumor-related DNA copy number changes using a genome-wide scoring approach. PLoS Comput Biol. 2010; 6: e1000631. http://dx.doi. org/10.1371/journal.pcbi.1000631

[11] MAW, YANGD, GUY, GUOX,ZHAOW et al. Finding diseasespecific coordinated functions by multi-function genes: insight into the coordination mechanisms in diseases. Genomics. 2009; 94: 94-100. http://dx.doi.org/10.1016/j.ygeno.2009.05.001

[12] YEANG C-H, MCCORMICK F, LEVINE A. Combinatorial patterns of somatic gene mutations in cancer. FASEB J. 2008; 22: 2605-2622. http://dx.doi.org/10.1096/fj.08-108985

[13] GU Y, ZHAO W, XIA J, ZHANG Y, WU R et al. Analysis of pathway mutation profiles highlights collaboration between cancer - associated superpathways. Hum Mutat. 2011; 32: 1028-1035. http://dx.doi.org/10.1002/humu.21541

[14] MANN KM, WARD JM, YEW CCK, KOVOCHICH A, DAWSON DW et al. Sleeping Beauty mutagenesis reveals cooperating mutations and pathways in pancreatic adenocarcinoma. Proc Natl Acad Sci. 2012; 109: 5934-5941. http://dx.doi.org/10.1073/pnas.1202490109

[15] TORKAMANI A, SCHORK NJ. Identification of rare cancer driver mutations by network reconstruction. Genome Res. 2009; 19: 1570-1578. http://dx.doi.org/10.1101/gr.092833.109

[16] UREN AG, KOOL J, MATENTZOGLU K, DE RIDDER J, MATTISON J et al. Large-Scale Mutagenesis in $<\mathrm{i}>\mathrm{p} 19 \mathrm{ARF}<$ / $\mathrm{i}>$-and $<\mathrm{i}>$ p53 $<$ i $>$-Deficient Mice Identifies Cancer Genes and Their Collaborative Networks. Cell. 2008; 133: 727-741. http://dx.doi.org/10.1016/j.cell.2008.03.021

[17] GU Y, YANG D, ZOU J, MA W, WU R et al. Systematic interpretation of comutated genes in large-scale cancer mutation profiles. Mol Cancer Ther. 2010; 9: 2186-2195. http://dx.doi. org/10.1158/1535-7163.MCT-10-0022 
[18] DA WEI HUANG BTS, LEMPICKI RA. Systematic and integrative analysis of large gene lists using DAVID bioinformatics resources. Nat Protoc. 2008; 4: 44-57. http://dx.doi. org/10.1038/nprot.2008.211

[19] OGATA H, GOTO S, SATO K, FUJIBUCHI W, BONO H et al. KEGG: Kyoto Encyclopedia of Genes and Genomes. Nucleic Acids Res. 1999; 27: 29-34. doi: gkc043 [pii].

[20] SUGIMURA H, YAMADA H, KAGEYAMA S, YAMAMURA Y, YOKOTA N et al. Glioblastoma: Germline Mutation of TP53. Tumors of the Central Nervous System, Volume 2. Springer; 2011. p. 31-38.

[21] OHGAKI H, DESSEN P, JOURDE B, HORSTMANN S, NISHIKAWA T et al. Genetic Pathways to Glioblastoma A Population-Based Study. Cancer Res. 2004; 64: 6892-6899. http://dx.doi.org/10.1158/0008-5472.CAN-04-1337

[22] BONAVIA R, MUKASA A, NARITA Y, SAH DW, VANDENBERG $S$ et al. Tumor heterogeneity is an active process maintained by a mutant EGFR-induced cytokine circuit in glioblastoma. Genes Dev 2010; 24: 1731-1745. http://dx.doi. org/10.1101/gad.1890510

[23] CHO J, PASTORINO S, ZENG Q, XU X, JOHNSON W et al. Glioblastoma-derived epidermal growth factor receptor carboxylterminal deletion mutants are transforming and are sensitive to EGFR-directed therapies. Cancer Res. 2011; 71: 7587-7596. http://dx.doi.org/10.1158/0008-5472.CAN-11-0821

[24] WANG SI, PUC J, LI J, BRUCE JN, CAIRNS P et al. Somatic mutations of PTEN in glioblastoma multiforme. Cancer Res. 1997; 57: 4183-4186.

[25] SMITH JS, TACHIBANA I, PASSE SM, HUNTLEY BK, BORELL TJ et al. PTEN mutation, EGFR amplification, and outcome in patients with anaplastic astrocytoma and glioblastoma multiforme. J Natl Cancer Inst. 2001; 93: 1246-1256. http://dx.doi.org/10.1093/jnci/93.16.1246

[26] KRAUS JA, GLESMANN N, BECK M, KREX D, KLOCKGETHER T et al. Molecular analysis of the PTEN, TP53 and CDKN2A tumor suppressor genes in long-term survivors of glioblastoma multiforme. J Neurooncol. 2000; 48: 89-94. http://dx.doi.org/10.1023/A:1006402614838

[27] GENG H, HSIEH P. Molecular Mechanisms and Functions of DNA Mismatch Repair. DNA Alterations in Lynch Syndrome. Springer; 2013. p. 25-45. http://dx.doi.org/10.1007/978-94007-6597-9_2

[28] HOEIJMAKERS JH. Genome maintenance mechanisms for preventing cancer. Nature. 2001; 411: 366-374. http://dx.doi. org/10.1038/35077232

[29] FELSBERG J, THON N, EIGENBROD S, HENTSCHEL B, SABEL MC et al. Promoter methylation and expression of MGMT and the DNA mismatch repair genes MLH1, MSH2, MSH6 and PMS2 in paired primary and recurrent glioblastomas. Int J Cancer. 2011; 129: 659-670. http://dx.doi. org/10.1002/ijc.26083

[30] TANG Y, HE W, WEI Y, QU Z, ZENG J et al. Screening Key Genes and Pathways in Glioma Based on Gene Set Enrichment Analysis and Meta-analysis. J Mol Neurosci. 2013: 1-9.

[31] SER O NV, DELFINO KR, SOUTHEY BR, BEEVER JE, RODRIGUEZ-ZAS SL. Cell cycle and aging, morphogenesis, and response to stimuli genes are individualized biomarkers of glioblastoma progression and survival. BMC Med Genomics. 2011; 4: 49. http://dx.doi.org/10.1186/1755-8794-4-49

[32] DE GROOT J, SONTHEIMER H. Glutamate and the biology of gliomas. Glia. 2011; 59: 1181-1189. http://dx.doi. org/10.1002/glia.21113

[33] EICHHORN PJ, ROD N L, GONZ LEZ-JUNC A, DIRAC A, GILI M et al. USP15 stabilizes TGF-[beta] receptor I and promotes oncogenesis through the activation of TGF-[beta] signaling in glioblastoma. Nat Med. 2012: 429-435.

[34] KANU OO, HUGHES B, DI C, LIN N, FU J et al. Glioblastoma multiforme oncogenomics and signaling pathways. Clinical medicine Oncology. 2009; 3: 39.

[35] JOHNSON MD, JENNINGS MT, GOLD LI, MOSES HL. Transforming growth factor- $\beta$ in neural embryogenesis and neoplasia. Hum Pathol. 1993; 24: 457-462. http://dx.doi. org/10.1016/0046-8177(93)90156-B

[36] PAULUS W, BAUR I, HUETTNER C, SCHMAUBER B, ROGGENDORF W et al. Effects of Transforming Growth Factor-[beta] 1 on Collagen Synthesis, Integrin Expression, Adhesion an Invasion of Glioma Cells. Journal of Neuropathology \& Experimental Neurology. 1995; 54: 236-244. http://dx.doi.org/10.1097/00005072-199503000-00010

[37] GAO Y, VASILYEV DV, GONCALVES MB, HOWELL FV, HOBBS C et al. Loss of retrograde endocannabinoid signaling and reduced adult neurogenesis in diacylglycerol lipase knockout mice. J Neurosci. 2010; 30: 2017-2024. http://dx.doi. org/10.1523/JNEUROSCI.5693-09.2010

[38] JACOBSSON SO, WALLIN T, FOWLER CJ. Inhibition of rat C6 glioma cell proliferation by endogenous and synthetic cannabinoids. Relative involvement of cannabinoid and vanilloid receptors. J Pharmacol Exp Ther. 2001; 299: 951-959.

[39] VELASCO G, GALVE-ROPERH I, S NCHEZ C, BL ZQUEZ C, GUZM N M. Hypothesis: cannabinoid therapy for the treatment of gliomas? Neuropharmacology. 2004; 47:315-323. http://dx.doi.org/10.1016/j.neuropharm.2004.04.016

[40] SCHLEY M, ST NDER S, KERNER J, VAJKOCZY P, SCH PFER $G$ et al. Predominant CB2 receptor expression in endothelial cells of glioblastoma in humans. Brain Res Bull. 2009; 79: 333-337. http://dx.doi.org/10.1016/j.brainresbull.2009.01.011

[41] GARDNER B, ZU LX, SHARMA S, LIU Q, MAKRIYANNIS $A$ et al. Autocrine and paracrine regulation of lymphocyte CB2 receptor expression by TGF- $\beta$. Biochem Biophys Res Commun. 2002; 290: 91-96. http://dx.doi.org/10.1006/bbrc.2001.6179

[42] CHEN X, ZANG W, XUE F, SHEN Z, ZHANG Q. Bioinformatics analysis reveals potential candidate drugs for different subtypes of glioma. Neurol Sci. 2012: 1-5.

[43] YAMAGUCHI H, CONDEELIS J. Regulation of the actin cytoskeleton in cancer cell migration and invasion. Biochimica et Biophysica Acta (BBA)-Molecular Cell Research. 2007; 1773: 642-652. http://dx.doi.org/10.1016/j.bbamcr.2006.07.001

[44] STEGH AH,DEPINHORA. Beyond effector caspase inhibition: Bcl2L12 neutralizes p53 signaling in glioblastoma. Cell Cycle. 2011; 10: 33-38. http://dx.doi.org/10.4161/cc.10.1.14365

[45] ZOHRABIAN VM, FORZANI B, CHAU Z, MURALI R, JHANWAR-UNIYAL M. Rho/ROCK and MAPK signaling pathways are involved in glioblastoma cell migration and proliferation. Anticancer Res. 2009; 29: 119-123. 